\title{
Fenomen kobiecości w wyobraźni poetyckiej Bolesława Leśmiana na tle europejskiej refleksji antropologicznej
}

W pierwszych dekadach XX wieku, w których przyszło tworzyć Bolesławowi Leśmianowi, szczególny wpływ na ukształtowanie dominującego wówczas obrazu kobiety wywarły mizoginiczne koncepcje filozoficzne Artura Schopenhauera, Fryderyka Nietzschego i Ottona Weiningera. W twórczości Leśmiana, wielkiego admiratora kobiecości we wszystkich jej przejawach, fenomen ten przyjmuje kształt odbiegający zdecydowanie od schematów epoki, przybiera cechy figur archetypowych i mitycznych. Schopenhauer, Nietzsche i Weininger demitologizują fenomen kobiecości, Leśmian dokonuje jego remitologizacji.

\section{Fenomen kobiecości w perspektywie filozoficznej przełomu XIX i XX wieku}

Zagadnienie metafizyki płci, poddane analizie filozoficznej przez Schopenhauera, Nietzschego i Weiningera, w kręgach środowisk twórczych Europy okresu modernizmu i dwudziestolecia międzywojennego budziło tak duże zainteresowanie, że nieznajomość tych autorów odczytywana była jako rażący deficyt wykształcenia ${ }^{\mathrm{I}}$. Schopenhauer swoje poglądy na metafizykę płci przedstawił w rozprawie $O$ kobietach, zamieszczonej w zbiorze zatytułowanym Parerga $i$ Paralipomena, w pracy $O$ podstawie moralności oraz w tekście Metafizyka stosunków płciowych, zawartym w fundamentalnej rozprawie Świat jako wola i przedstawienie $^{2}$. Filozof podjął próbę demitologizacji obrazu kobiety,

I Zob. M. Uliński, Kobieta i mężczyzna. Dzieje refleksji filozoficzno-spotecznej, Kraków 2001.

2 Zob. A. Schopenhauer, O kobietach, przeł. M. Uliński, „Principia” 1992, nr V; idem, O podstawie moralności, przeł. Z. Bossakówna, Warszawa 1988; 
proponując spojrzenie na kobiecość przez pryzmat jej zdolności prokreacyjnych. Schopenhauerowska wizja związków łączących mężczyznę i kobietę należy do kręgu antropologii tragicznej i fatalistycznej - człowiekiem rządzi instynkt płciowy, „demon zniszczenia i zagłady” realizujący „geniusz gatunku”, irracjonalna, dynamiczna wola, ślepa i ekspansywna. Wypełnieniem się woli gatunku jest gatunkowo optymalna prokreacja, instynktowny dobór kojarzy przyszłych rodziców w ten sposób, aby wszelkie odchylenia od „idealnego typu gatunkowego” uległy w potomku korekcie:

Jest coś zadziwiającego i niezrozumiałego w tym troskliwem oglądaniu się, w tych tajemniczych spojrzeniach, któremi się obrzucają zakochani. Uważne to badanie jest to rozmyślanie geniuszu gatunku nad przyszłem indywiduum, rozmyślanie nad kombinacyją jego cech i własności³.

Instynkt gatunkowy, mając na względzie wyłącznie o jakość przyszłego potomstwa, często unieszczęśliwia mężczyznę i kobietę:

Małżeństwa $\mathrm{z}$ miłości zawierają się $\mathrm{w}$ interesach gatunku, nie zaś samych zakochanych. Połączeni z sobą w imię obcego sobie celu, razem życie prowadzą, pomimo różnorodności charakterów i poglądów. Małżeństwa z miłości bywają najczęściej nieszczęśliwe

W Schopenhauerowskiej metafizyce płci kobieta reprezentuje siły przyrody (,,jest daleko lepiej od mężczyzny uzdolnioną do kierowania się instynktem" 5), mężczyzna uosabia to, co duchowe. Kultura europejska obdarzyła kobietę perwersyjnym kultem, dla którego nie ma uzasadnienia ani w jej przymiotach duchowych, ani fizycznych: „Niską, wąskoramienną, szerokobiodrą i krótkonogą płeć nazwać piękną mógł jedynie zamroczony popędem płciowym męski intelekt" ${ }^{6}$. Schopenhauer proponuje wprowadzenie do kultury europejskiej poligamii, która położyłaby kres wynaturzonemu kultowi kobiety i doprowadziła do zniesienia hipokryzji obyczajowych stosunków erotycznych:

idem, Psychologia mitości, przeł. A.L., Warszawa 1901 (jest to przekład rozdziału Methaphisik der Geschlechtsliebe z drugiego tomu Die Welt als Wille und Vorstellung); idem, Świat jako wola i przedstawienie, przeł. J. Garewicz, t. 2, Warszawa 1995.

3 A. Schopenhauer, Psychologia miłości, cyt. za: M. Uliński, op.cit., s. 202.

Ibidem, s. 203.

Ibidem.

${ }^{6}$ A. Schopenhauer, O kobietach, $\$ 369$. 
„Kobieta jako istota podporządkowana powróci na swoje właściwe miejsce, a dama, to monstrum cywilizacji i chrześcijańsko- germańskiej głupoty, z jej śmiesznymi pretensjami do respektu i czci zniknie ze świata" 7 .

Kolejny ze wspomnianych filozofów, Nietzsche, zasłynął z prowokacyjnych aforyzmów, stanowiących dopełnienie jego poglądów antropologicznych: „kobieta doskonała jest wyższym typem człowieka, niż doskonały mężczyzna, ale także czymś o wiele rzadszym” ${ }^{8}$; „Idziesz do kobiet? Nie zapomnij bicza” ${ }^{9}$. Nietzscheańskie ujęcie tematu relacji płci podkreśla bardzo wyraźnie jej antagonistyczny charakter, akcentując antropologiczną odrębność mężczyzny i kobiety. Kobiety, przez właściwy im kult pokojowości, ostentacyjne manifestowanie własnej słabości, gloryfikowanie litości, potrzebę poczucia bezpieczeństwa, wykazują brak woli mocy, są zatem wyznawczyniami moralności niewolniczej. Mężczyzna, reprezentujący moralność panów, to człowiek twórczy, wolny, wojownik: „człowiek wyzwolony gardzi nikczemną błogością, o której marzą przekupnie, chrześcijanie, krowy, kobiety” " ${ }^{\text {ro }}$ Kobieta, „delikatne, cudnie dzikie, a nieraz miłe zwierzę domowe" budzi w mężczyźnie-wojowniku zaciekawienie, niekiedy nawet lęk:

To czem kobieta wzbudza dla siebie cześć, a nieraz trwogę, jest jej natura, „naturalniejsza” od natury męskiej, jej iście drapieżna, przebiegła gibkość, jej szpon tygrysi pod rękawiczką, naiwność jej egoizmu, jej zawziętość i wewnętrzna dzikość, nieuchwytność, bezbrzeżność, błędność jej cnót i żądz. Prócz lęku, piękne to i niebezpieczne kocię, „kobieta”, budzi dla siebie współczucie, gdyż zda się bardziej cierpiącem, łacniej uraźliwem, więcej miłości potrzebującem i na boleśniejsze rozczarowania skazanem od każdego innego zwierzęcia ${ }^{I I}$.

Relacja między mężczyzną i kobietą ma charakter niesymetryczny, kobieta „pragnie kogoś, kto bierze, kto sam siebie nie daje, nie rozdaje; kobieta darowuje się, mężczyzna przyjmuje -

7 Ibidem, $\$ 370$.

${ }^{8}$ F. Nietzsche, Ludzkie, arcyludzkie, przeł. K. Drzewiecki, Warszawa 1908, s. 326 .

9 F. Nietzsche, Tako rzecze Zaratustra, przeł. W. Berent [brak informacji o miejscu i dacie wydania], s. 76 .

to F. Nietzsche, Zmierzch bożyszcz, przel. S. Wyrzykowski, Warszawa 1909-1910, s. 101.

II F. Nietzsche, Poza dobrem i złem, przeł. S. Wyrzykowski, Warszawa 1907, s. 202-204. 
sądzę, że żadne społeczne umowy nie pokonają tego przeciwieństwa natury" ${ }^{2}$.

Pteć $i$ charakter. Rozbiór zasadniczy, opus magnum Weiningera, książkowa wersja jego pracy doktorskiej obronionej w roku 1902 na Uniwersytecie Wiedeńskim, ukazała się kilka miesięcy przed samobójczą śmiercią jej dwudziestotrzyletniego autora i natychmiast zyskała światowy rozgłos ${ }^{13}$. Uważa się, że antyfeministyczne i mizoginiczne tendencje epoki w dziele Weiningera przybrały wymiar totalny ${ }^{\mathrm{I}}$. Relacja między mężczyzną a kobietą w tej teorii ma charakter manichejski, towarzyszy jej nieustanna, dramatyczna walka kobiecej cielesności $\mathrm{z}$ męską duchowością, która rozgrywa się nie tylko w świecie zewnętrznym, bowiem mężczyzna i kobieta muszą konfrontować się nieustannie $\mathrm{z}$ własną androgynicznością. Podstawą antropologii Weiningera jest teza o względności gonochoryzmu: „Wszystkie właściwości płci męskiej dadzą się także odszukać w płci żeńskiej, choćby tylko w śladach bardzo słabo rozwiniętych; i na odwrót wszystkie kobiece znamiona płciowe istnieją gdzieś u mężczyzny" ${ }^{15}$. Weininger podjął próbę stworzenia teoretycznego modelu „kobiety idealnej”, mającego reprezentować kwintesencję kobiecości, oraz „mężczyzny idealnego”, tj. wzorca męskości. Elementami konstytutywnymi Weiningerowskiego wzorca „kobiety absolutnej” są cielesność, seksualność (ze względu na kryterium funkcji kobiecej seksualności filozof wyróżnia dwa modele antropologiczne: kobietę-matkę i kobietę-heterę), duchowa, intelektualna i moralna nicość, nielogiczność, brak abstrakcyjnej fantazji (stąd w historii kultury brak nazwisk wybitnych kobiet w takich dziedzinach, jak filozofia, rzeźba, architektura i muzyka; henidalny, tj. posługujący się

ז2 F. Nietzsche, Wiedza radosna, przeł. L. Staff, Warszawa 1910-1911, s. 330 .

I3 Wywarła bardzo silny wpływ na twórczość A. Strindberga, S. Przybyszewskiego, Witkacego. Zob. L. Sokół, Metafizyka płci: Strindberg, Weininger, Witkacy, „Pamiętnik Literacki” 1985, z. 4.

${ }^{4} 4$ Zob. M. Uliński, op.cit., s. 212.

I5 O. Weininger, Pteć $i$ charakter. Rozbiór zasadniczy, przel. O. Ortwin, Łódź 1921, s. 16. Według teorii antropologicznej Weiningera należałoby dla każdego człowieka opracować diagram, wskazujący stopień jego męskości i kobiecości, następnie diagram ten stosować jako podstawowe kryterium doboru par. Weininger zaproponował również modyfikację zabiegów transfuzji krwi - stosowaną powszechnie metodę kopenhaskiego biologa J. Steenstrupa, polegającą na podawaniu mężczyznom w czasie transfuzji wyłącznie krwi męskiej, kobietom - krwi kobiecej. Weininger pragnął ją udoskonalić przez wcześniejsze określenie procentowego udziału płci męskiej i żeńskiej u danego osobnika, co pozwoliłoby szukać dawcy o podobnym diagramie płciowości. Por. M. Uliński, op.cit., s. 213. 
niejasnymi, emocjonalnymi i subiektywnymi obrazami sposób myślenia predysponuje je raczej do uprawiania poezji, malarstwa i teozofii). „Mężczyzna absolutny” to podmiotowość, intelekt, moralność, kreatywność, duchowość. Według Weiningera brak kobiecej duchowości dostrzegli w historii myśli ludzkiej już Chińczycy, wzbraniający kobietom dostępu do raju Mahomet, a w kulturze europejskiej Arystoteles. Zgodnie z teorią względności gonochoryzmu procentowy udział pierwiastka męskiego i żeńskiego w każdym indywiduum przybiera różne proporcje, co sprzyja zjawisku transcendowania płci. Stąd w Weiningerowskiej teorii płci pojawia się krytyka zakorzenionej w kulturze uniformizacji wychowania w obrębie płci. Społeczeństwo narzuca określone stereotypy zachowania mężczyznom i kobietom wbrew ich naturalnym skłonnościom, marnotrawiąc naturalne predyspozycje każdego człowieka i zmuszając go do hipokryzji oraz cierpienia. Wychowanie we wczesnym okresie życia powinno być zatem zindywidualizowane, koedukacyjne i wszechstronne, każdy powinien odnaleźć swoje predyspozycje zgodnie $\mathrm{z}$ wrodzoną proporcją tkwiącego $\mathrm{w}$ nim pierwiastka męskości i kobiecości. Pomimo androgyniczności i indywidualnej, wrodzonej niejednoznaczności płciowej każdego indywiduum podstawą antropologicznych koncepcji Weiningera pozostaje przeświadczenie o absolutnej podrzędności pierwiastka kobiecego wobec energii męskiej mającej moc kulturotwórczą.

\section{Feminizacja ikon czasu}

Literatura początku XX wieku, do której chronologicznie należy twórczość Leśmiana, inspirowana filozofią Schopenhauera, rozszczepiła tradycyjne pojęcie miłości na Geschlechtsliebe (popęd płciowy) i caritas (metafizyczna identyczność). Mizoginiczne i pełne resentymentów traktaty filozoficzne Nietzschego oraz Weiningera, podejmujące problem antagonizmu płci, ugruntowały w kulturze obraz femme fatale, kobiecości zgubnej, który zdominował epokę. W opozycji do tych tendencji w wyobraźni poetyckiej Leśmiana miłość stanowi prajednię, jest „religią miłości”, „miłością zwierzęco-ludzko-pankosmiczną" ${ }^{16}$. Poeta zafascynowany wyobraźnią człowieka pierwotnego w konstrukcji swoich literackich kochanek odwołuje się do symboliki obrzędowej. Jego wyobrażeniowe figury kobiece, jako byty me-

I6 W. Gutowski, Nagie dusze i maski. O młodopolskich mitach miłości, Kraków 1997, s. 336. 
diacyjne, wyznaczają drogę możliwego przejścia między zaświatami a krainą śmiertelników, łączą dwa brzegi przepaści rozdzielającej ekumenę od obszaru sacrum ${ }^{\mathrm{I7}}$.

W sferze swojej poetyckiej wyobraźni Leśmian silnie akcentuje analogie między sakralnością kobiety a sakralnością Tellus Mater, przyjmuje postawę neofity, kobietę obdarza mocą wtajemniczania w misterium regeneracji. Hierogamia wieńczy inicjację, umożliwia regressus ad uterum. Leśmianowskie kochanki: Majka, Dziwożona, Południca, Rusałka Leśna - epifanie Tellus Mater - to „mityczne sieroty” lub osoby kalekie, byty mediacyjne, mające zdolność ujawniania zaświatowej wiedzy. Jako bezdomne istoty telluryczne stają się dziećmi Pammetor Ge Ziemi Matki Wszystkiego ${ }^{18}$. Swoją magię miłosną poeta buduje, sięgając do wyobrażeń z kręgu demonologii słowiańskiej, będącej niezwykle istotnym źródłem inspiracji pisarza od najmłodszych lat związanego z folklorem Ukrainy ${ }^{\text {I9 }}$. Majka (Klechdy polskie), $\mathrm{w}$ antropologii kultury zwana też rusałką, płaczką leśną, miawką lub nawką, wywodzi się ze wschodniosłowiańskiego kręgu demonologii leśnej ${ }^{20}$. W konstrukcji postaci Majki akcentuje poeta silnie jej noktomorfizm i związki z płodnymi siłami natury: „Smukła, ze światłem księżyca na obnażonych ramionach” ${ }^{21}$. Jednocześnie wprowadza zabiegi mające udaremnić hierogamię - kochankowie mają odmienne postawy epistemologiczne (poddany magii miłosnej wiejski pragmatyk Marcin Dziura jest racjonalistą, rusałka porusza się w przestrzeni magicznej), różne statusy ontologiczne (człowiek - demon) i oczekiwania estetyczne (rybi ogon rusałki budzi w Marcinie odrazę). Bohater, wprowadzony w krąg kultury magicznej, nie pozwala się w niej osadzić. Lęk przed Tanatosem spowoduje, że Dziura nie przekroczy kręgu sacrum, pozostanie w sferze profanicznej, bez-

I7 Por. J. Kowalska, Taniec drzewa życia. Uniwersalia kulturowe w tańcu, Warszawa 1991.

I8 Na gruncie fenomenologii religii bardzo silnie akcentowana jest nie tylko teofania telluryczna Ziemi (Tellus Mater), ale też jej otchłań chtoniczna - Pammetor $G e$ jawi się jako bogini świata oraz zaświatów i w takiej funkcji objawia się w wyobraźni poetyckiej B. Leśmiana. Por. M. Eliade, Traktat o bistorii religii, przeł. J. Wierusz-Kowalski, Łódź 1993; idem, Historia wierzeń i idei religijnych, t. 1, przeł. S. Tokarski, Warszawa 1988; G. van der Leeuw, Fenomenologia religii, przeł. J. Prokopiuk, Warszawa 1978.

I9 A. Stern napisał: „Nikt lepiej od niego nie znał wszystkich dziwów i guseł starej słowiańskiej Polski”. A. Stern, Powroty Bolestawa Leśmiana, w: Wspomnienia o Bolestawie Leśmianie, red. Z. Jastrzębski, Lublin 1966, s. 337.

${ }^{20}$ Majki nie są jedynymi znanymi słowiańszczyźnie żeńskimi demonami leśnymi. W kulturze tradycyjnej pojawiają się też drzewice - duchy drzew i dziewonie - opiekunki runa leśnego. Zob. L. Pełka, Polska demonologia ludowa, Warszawa 1987.

${ }^{21}$ B. Leśmian, Klechdy polskie, Kraków 1999, s. 106. 
piecznej, bo znanej. Próba inicjacji doprowadzi zaledwie do rozpoznania sytuacji egzystencjalnej bohatera, odsłaniając sferę jego lęków. W strukturze postaci innej Leśmianowskiej figury Tellus Mater, Dziwożony ${ }^{22}$ (Klechdy polskie), dominuje symbolika erotyczna - główna postać kobieca to nereida, obdarzona ciepłym, nagim, lepkim od miodu ciałem, ustami nabrzmiałymi krwią i językiem czerwonym jak mak ${ }^{23}$. Jedynym znakiem hierogamii w utworze czyni poeta, zamieszkiwane przez Dziwożonę, drzewo - axis mundi, miejsce miłosnego spotkania nieba i ziemi. Poddany inicjacji Podlasiak, upiór dębowy, jako jedyny spośród uczestników miłosnego transu dostąpi wtajemniczenia w misterium odrodzenia, naznaczony krwią z pokąsanych przez komary ust rusałki. Wyobrażenie Południcy ${ }^{24}$, znanej w antropologii kultury pod nazwą Żytniej Baby, zaczerpnął Leśmian z mitologii starosłowiańskiej, w której jako strażniczka Bogini Siemi ${ }^{25}$ pełniła ważną funkcję w obrzędach wegetacyjnych ${ }^{26}$. W wyobraźni autora Łąki dzięki mediacji tego chtonicznego demona polnego odbywa się misterium spotkania człowieka z wiecznością Swidryga i Midryga w miłosnej ekstazie (inicjacja przyjmuje tu postać opętańczego tańca) „ujrzą otchłań śmierci czarną od ogromu", jednak, paradoksalnie, byty te dotychczas wydziedziczone poczują się wreszcie ,jak u siebie w domu” ${ }^{27}$. Rusałka Leśna, bohaterka dwóch dramatów mimicznych Pierrot $i \mathrm{Ko}-$ lombina oraz Skrzypek opętany, wystylizowana przez autora na Demeter-Persefonę (wegetacyjna symbolika atrybutów, zejście do świata podziemnego), prowadzi swego kochanka Pierrota-Alaryela ${ }^{28}$, przez miłosne wtajemniczenie, do wyzwolenia z ograniczeń ludzkiej śmiertelności (wyobrażonego pod postacią blasku ${ }^{29}$. W wyobraźni poetyckiej Leśmiana kobiecy demon, wykorzystując swoją erotyczno-chtoniczną potęgę, ofiarowuje

${ }_{22}$ Demon leśny wywodzący się z tradycji południowosłowiańskiej, głównie czeskiej. Por. L. Pełka, op.cit.; K. Moszyński, Kultura ludowa Stowian, t. 2, Warszawa 1967; P. Kowalski, Znaki śrwiata. Omen, przesad, znaczenie, Warszawa-Wrocław 1998.

23 Zob. B. Leśmian, Klechdy polskie, s. 226-227.

${ }_{24}$ Zob. utwór Świdryga i Midryga z tomu Ląa.

25 Słowiański wariant Tellus Mater.

${ }^{26}$ Por. C. Białczyński, Stworze $i$ zdusze, czyli starostowiańskie boginki i demony, Kraków 1993.

27 B. Leśmian, Poezje zebrane, red. A. Madyda, Toruń 1995, s. 205.

${ }_{28}$ Dramaty Pierrot i Kolombina oraz Skrzypek opętany traktuję jako kompozycyjną całość ze względu na typową dla myślenia mitycznego, a obecną w obydwu utworach, powtarzalność scen i sekwencji symbolicznych. Stąd pojawiające się w tekście stałe zestawienie Pierrot-Alaryel. Por. B. Leśmian, Skrzypek opętany, oprac. R.H. Stone, Warszawa 1985.

${ }_{29}$ Nieśmiertelność, poprzedzoną rytualną śmiercią, przynosi Skrzypkowi Opętanemu wąż - wysłannik bóstw chtonicznych. 
„topielcowi zieleni” surogat wieczności, godząc go z nieuchronnością przemijania ${ }^{\circ}$. W Zdziczeniu obyczajów pośmiertnych do poetyckiego opisu fenomenu kobiecości pisarz wykorzystuje chwyt przemiany w drzewo - zdradzona i poniżona przez Sobstyla Krzemina staje się wierzbą, „co patrzy liściasto” ${ }^{31}$. Odwołując się do zakorzenionych w symbolice regeneracyjnej rytów hierogamii (miłosne spotkanie kochanków Sobstyla i Marcjanny odbywa się w ukwieconym ogrodzie) i śmierci inicjacyjnej, jako warunków koniecznych do odrodzenia, Leśmian odprawia i ożywia na cmentarzu misterium wiecznego powrotu. Postacie dramatu uwikłane w miłosny trójkąt, przeżywszy po raz wtóry swoją śmierć, mogą doświadczyć wieczności: „drobnej - stąd dotąd - od bramy do wzgórka" ${ }^{2}$.

Leśmianowskie kreacje kochanek to poetycko przetworzone rudymentarne doświadczenia egzystencjalne, pojawiające się w efemizujących lęki tanatyczne człowieka obrzędach inicjacyjnych (obrzędach przejścia), w których hierogamia stanowi jeden z podstawowych rytów ${ }^{33}$. W twórczości Leśmiana Bóg-Ojciec opuścił człowieka - „spadły z nieba bezwolnie wraz z poranną rosą, drzemie w macierzankach poległy na wznak" 34 . Telluryczna magia miłosna zastępuje $\mathrm{w}$ wyobraźni poetyckiej autora uraniczną obietnicę nieśmiertelności. Regeneracyjna symbolika występuje w konstrukcji wszystkich zaprezentowanych Leśmianowskich postaci kobiecych. Eleuzyjska Demeter jest „matką ziarna” - obraz zboża pojawia się w polu semantycznym figury Majki („,czekałam na ciebie w pszenicy, jak się czeka w alkowie” ${ }_{35}$ ) i Południcy („Żytnia Baba” przebywała na polach tylko w czasie wegetacji zbóż). Mak, drugi atrybut greckiej bogini płodności, jest ważnym elementem obrazowania Dziwożony (usta nabrzmiałe krwią, język czerwony jak mak). Rusałka Leśna nosi wyraźne ślady stylizacji na bóstwo chtoniczne (zejście pod ziemię, odrodzenie, epifania pod postacią blasku). W konstrukcji wszystkich tych postaci kobiecych Leśmian akcentuje

$3^{\circ}$ Leśmian, wyjątkowo boleśnie odczuwający nieuchronność przemijania, myślał bardzo poważnie o poddaniu się operacji mającej zatrzymać proces starzenia. Spotkał się nawet w tym celu z profesorem Woronowem przeprowadzającym takie zabiegi w Paryżu. Zob. Wspomnienia o Bolestawie Leśmianie, s. 11, 102, 143, 189, 206-207. Do zabiegu nigdy nie doszło, pozostał świat wyobrażeń jako jedyny obszar eufemizacji śmierci.

$3^{\text {I }}$ B. Leśmian, Zdziczenie obyczajów pośmiertnych, oprac. J. Trznadel, Kraków 1998, s. 31.

${ }^{2}$ Ibidem, s. 18.

33 Zob. M. Buchowski, Magia i rytuat, Warszawa 1993.

34 B. Leśmian, Dżananda, w: idem, Poezje reybrane, oprac. J. Trznadel, Wrocław 1983, s. 155.

35 B. Leśmian, Klechdy polskie, s. 103. 
bardzo wyraźnie ich noktomorfizm (władza Majki rozpoczyna się wraz z zachodem słońca i kończy o świcie, Dziwożona nosi światło księżyca na nagich ramionach). Wyraźny w wyobraźni poetyckiej pisarza izomorfizm kobiety i księżyca wyraża, przez związki z symboliką płodności i śmierci, jeden z podstawowych archetypów regeneracji. Stąd w obrazach Leśmianowskich kochanek tak silna, obok symboliki erotycznej, obecność symboliki chtonicznej. Majka podróżuje na asfodelowej „Łące Pływającej”, Dziwożona zamieszkuje otchłań dziupli dębu, Rusałka Leśna objawia swą moc pod postacią blasku rozświetlającego mogiłę. Archaiczne misteria regeneracyjne przeprowadzały adepta przez symboliczną hierogamię, śmierć aż do odrodzenia. Wszystkie te ryty stanowią trzon Leśmianowskiej magii miłosnej. Kobiecy demon, wykorzystując swą erotyczno-chtoniczną potęgę, przez objawienie tajemniczej ciągłości życia i śmierci godzi epoptę z nieuchronnością przemijania. Figury wyobrażeniowe kobiety, reprezentujące w koncepcji antropologicznych struktur wyobraźni Gilberta Duranda nocny porządek obrazu, którego cechą podstawową są właściwości eufemizacyjne (dzięki zabiegowi coincidentia oppositorum zniesiona zostaje $\mathrm{w}$ warstwie wyobrażeniowej opozycja między życiem i śmiercią ${ }^{6}$ ), włączają w nieuchronny bieg czasu uspokajające figury, noszące w sobie symbolikę intymności, powtarzalności, cykliczności, regeneracji. Leśmianowskie kobiece figury wyobrażeniowe, $\mathrm{z}$ typową dla poety pozytywną waloryzacją kobiecego ciała, przekształcają śmiertelne strachy w obrazy pożądania, eufemizując wartości symboliczne Tanatosa.

Leśmianowska pozytywna interpretacja fenomenu kobiecości bliska jest antropologii Georga Simmla, który na przełomie XIX i XX wieku należał do najwybitniejszych, obok Nietzschego i Bergsona, reprezentantów filozofii życia. Podstawę jego teorii stanowiła koncepcja człowieka jako bytu przekraczającego granice (gatunku, świadomości, form, które tworzy). W odróżnieniu od przedstawicieli filozofii patriarchalnej Simmel przypisuje „wiecznej kobiecości” ważną rolę kulturotwórczą, jaką jest symboliczna kreacja domu ${ }^{37}$, mająca doniosłe konsekwencje natury egzystencjalnej (poczucie zakorzenienia w bycie). Intuicję kobiecą i wrodzoną jej pozalogiczność (w przeciwieństwie

${ }^{36}$ Zob. G. Durand, Les structures anthropologiques de l'imaginaire, Paris 1992.

37 H. Deutsch w swoich pracach poświęconych fenomenowi kobiecości wyróżnia trzy podstawowe figury mityczne, mające decydujący wpływ na kulturowy obraz kobiety: płodnej Demeter, bezdzietnej Pallas Ateny i androgynicznej Amazonki. Zob. np. H. Deutsch, The Psychology of Women, New York 1944. 
do przypisywanej kobiecie przez Weiningera nielogiczności) utożsamia ze zdolnością doświadczania najgłębszych tajemnic kosmicznych i metafizycznych. Kobieta w antropologii Simmla „przypomina swoją strukturą dzieło sztuki, w którym każda część ma sens ze względu na wszystkie pozostałe i strukturę całości najpełniejszej, jaką jest wszechświat" ${ }^{8}$.

Filozofia płci w teoriach antropologicznych Schopenhauera, Nietzschego i Weiningera zbudowana została na zasadzie dramatycznej opozycji erotycznej cielesności (pierwiastek kobiecy) i duchowości (pierwiastek męski) jako sił manichejskch. Leśmian traktuje kobiecą cielesność jako hierofanię. Kobieta, objawiając sakralność wszechświata, uczestniczy w jego porządku duchowym. To nowe objawienie, zgodne $\mathrm{z}$ nowoczesnym, fenomenologicznym postrzeganiem zjawiska cielesności, odwraca kierunek poszukiwania sensu, proponując, zamiast antagonizmu płci, ich harmonijne dopełnienie:

Z miłością erotyczną, która wiele jeszcze zawdzięcza rozmachowi popędu, wiąże się jeszcze inny, duchowy rozmach, z którego rodzi się nowe pragnienie i nowa zdolność, mianowicie pragnienie dobrowolnego potwierdzenia przez inną osobę oraz zdolność wzniesienia się - ponad ambiwalencję żądzy, oscylującej między miłością i nienawiścią - do jednoznaczności trwałego „tak” wobec Drugiego ${ }^{39}$.

\section{MARZENA KARWOWSKA}

\section{The phenomenon of femininity in the poetical imagination of Bolesław Leśmian against the background of European anthropological reflection}

In the early decades of the twentieth century the misogynist philosophical conceptions proposed by Schopenhauer, Nietzsche and Weininger exerted a particular influence upon the image of woman. In the literary output of Leśmian this phenomenon takes on the form decidedly divergent from the patterns prevalent at the time manifesting in the typical features of archetypal and mythical figures. In the construction of his literary lovers, Leśmian makes references to ritual symbolism. His almost hieratic female figures, notionally available to woman, guide the way in a possible passage between the beyond (spiritual world) and the world of mortals. The poet accentuates the analogies between the sacredness of woman and the sacrum of Tellus Mater and adopts the at-

$3^{8}$ G. Simmel, Bruchstücke aus einer Psychologie der Frauen, cyt. za: M. Uliński, op.cit., s. 230.

39 G. Haeffner, Wprowadzenie do antropologii filozoficznej, przeł. W. Szymona, Kraków 2006, s. 122. 
titude of a neophyte who endows women with the power of initiation into the mystery of regeneration. The notional female figures created by Leśmian, with the typical for the poet positive and exhilarating valorization of woman's body, have the power of euphemising thanatical fears and anxiety. Leśmian treats the corporeal nature of woman as hierophany: a female, revealing the sacral character of the universe, forms and contributes to its spiritual order. Schopenhauer, Nietzsche and Weininger demythologize the phenomenon of femininity, Leśmian remythologizes it back again.

MARZENA KARWOWSKA - dr, adiunkt w Instytucie Filologii Polskiej Uniwersytetu Łódzkiego. Prowadzi badania z zakresu mitokrytyki i antropologii wyobraźni, zrealizowała staże naukowe z tej dziedziny na uniwersytetach we Francji. Autorka książki Prapamięć uśpiona. Świat wyobrażeń Bolestawa Leśmiana (2008).

e-mail: marzenakarwowska@poczta.onet.pl 
